\title{
Complexities and diversity in archaeologies of Island Melanesia
}

\author{
James Flexner and Mathieu Leclerc
}

It has been over 20 years since Spriggs' (1997) synthesis The Island Melanesians was published. In the ensuing two decades, a massive and accelerating amount of archaeological fieldwork, analysis, and publication has taken place in the region (see Kirch 2017:55-183 for a recently updated synthesis). There have since been a number of synthetic works highlighting the archaeology of specific archipelagos in Island Melanesia, including Vanuatu (Bedford 2006; Bedford and Spriggs 2014), the Solomon Islands (Walter and Sheppard 2017) and Fiji (Burley 2013; Clark and Anderson 2009). There have also been periodic volumes covering the archaeology of the Lapita Cultural Complex, which is a phenomenon primarily located in Island Melanesia, though also in the neighbouring Polynesian archipelagos of Tonga and to a lesser extent Samoa (e.g. Bedford et al. 2007; Sand and Bedford 2010; Sand et al. 2015). As more sites are discovered, the notion of what Lapita is, where it is located and how to interpret possibly related findings remains a matter of vibrant debate.

This book is not intended as a new synthesis of Melanesian archaeology in the true sense. Rather, the book features a series of case studies highlighting the great diversity of contemporary approaches to archaeologies of Island Melanesia from a thematic perspective. The field is transforming rapidly in response to a variety of forces both inside and outside the discipline of archaeology. One of the more significant developments in 21st-century Melanesian archaeology is the emergence of a sense of 'salvage' archaeology, in which large-scale fieldwork is carried out to document sites ahead of economic development projects (Richards et al. 2016; Sand et al. this volume). We imagine this kind of research will become increasingly prominent in coming years.

In introducing this collection of essays, we focus on two significant themes that are immediately apparent to anyone who has worked in Melanesia: the great diversity of environmental and cultural processes that have shaped, and continue to shape, human life in the region; and the complexity of Melanesian societies, which is itself a highly diverse phenomenon.

At the outset, we should offer a caveat similar to the one that Kirch (2017:4) gives in a much broader-ranging synthesis of Pacific archaeology. When we refer to Island Melanesia, we are referring to a geographic region comprising the islands in the contemporary nation-states of Papua New Guinea, the Solomon Islands, Vanuatu, Fiji and the French colony of New Caledonia. This grouping makes sense because of the history of research in the Pacific, but it certainly does not reflect the complex culture histories of Melanesian people. The boundary with neighbouring Polynesia is problematic considering the long history of interaction and connections between the regions. Dumont d'Urville's tripartite division of the Pacific into Polynesia, Melanesia and Micronesia has remained influential in the ways that scholars understand the Pacific (Clark 2003) 
and how the inhabitants construct their identities. ${ }^{1}$ Dumont d'Urville created divisions that are still used heuristically, but it is well understood that the boundaries are in some ways inappropriate, particularly for the racialised division of Melanesia.

Thus, while Melanesia can be used to distinguish an area of sea and islands, it does not bear any relationship to the histories of the people who live in those islands. This is in contrast to Polynesia, which has been argued to represent a 'phyletic unit' composed of cultures with a traceable shared ancestry (Kirch and Green 2001). Roger Green (1991) long ago noted that Melanesia might be better conceived of in terms of Near Oceania, those islands that were colonised initially during the Pleistocene, and Remote Oceania, those islands first settled by Lapita-age populations beginning around 3000 years ago. Further, Dumont d'Urville's boundaries have always been permeable, and perhaps the clearest evidence for this is the presence of Polynesian Outliers, islands with Polynesian languages and cultural traits that are located within the geographic boundaries of Melanesia and Micronesia (Feinberg and Scaglion 2012).

\section{Diversity in Island Melanesia}

Melanesia is arguably the most linguistically diverse region of the world. From the Papuan languages of the New Guinea highlands and interiors of some high islands in the Solomon Islands (Reesink et al. 2009), to the immense number of Austronesian languages present in the small population of Vanuatu (Crowley 2000; François 2012), the level of diversity in the region is simply astonishing. This linguistic diversity is a reflection of the complex history of settlement in the region reaching back to the Pleistocene, though there is not necessarily a simple relationship between languages and populations (Posth et al. 2018).

Environmentally, Melanesia is also highly diverse. Island size varies from New Guinea, the world's second-largest island with an interior massif featuring many peaks that reach over $4000 \mathrm{~m}$ in height, to tiny atolls a few kilometres in surface area and no more than a few metres high at their highest point. Often the biogeographic variability of Melanesian islands is represented within small groups of neighbours. For example, the south of Vanuatu features two older, dormant volcanic high islands, Erromango and Aneityum; a still-active volcanic island, Tanna; a nearby coral atoll, Aniwa; and a makatea-type island of raised limestone, Futuna (Flexner et al. 2018). Islands also vary in terms of the sizes and productivity of fringing coral reefs and mangrove swamps, both of which were an essential resource for islanders, particularly as a source of fish and shellfish (see Oertle and Szabó this volume). On larger islands, it might be several days' walk from the interior to the sea. Islanders often adapted to this kind of ecological variability by developing complex exchange networks to redistribute surpluses and deficits not only of food but also other essentials such as oven stones, raw materials, finished tools and valuables (see Bayliss-Smith et al. this volume).

Cultural diversity, of course, goes hand in hand with this linguistic and biogeographical diversity. Histories of Melanesian islands are both variable, and often follow radically different trajectories from many Old World-focused archaeological models. For example, Papua New Guinea's highlands produced one of the earliest inventions of agriculture in the world (Golson et al. 2017). The concept of the 'Neolithic revolution' expected to accompany such an invention does not apply readily to this case, however (Denham this volume). Melanesian ritual practices took on a variety of forms, some involving monumental stone constructions, some not (Bedford this volume). Melanesians had a remarkable diversity of ways of treating the dead and mediating

1 There are numerous examples of grassroots events associated with Melanesian culture, such as the Melanesian Arts and Cultural Festival, the Melanesian Regional Championships (Athletics), Wansol Melanesian Music Festival, etc. 
relationships with ancestors (Valentin et al. 2011; Valentin and Sand this volume). Social organisation was likewise remarkably diverse, and it is here that we turn to the concept of complexity for understanding Melanesia.

\section{Melanesian complexities}

In what has now become a classic work in cultural anthropology, Sahlins (1963) defined a concept of 'big man' societies that he saw as typical of Melanesian social complexity, in contrast to the hereditary titles passed down through Polynesian chiefdoms. This work has been challenged on various fronts, including suggestions that the big man phenomenon was associated specifically with Papuan, as opposed to Austronesian-speaking groups (Scaglion 1996). More critically, the big man societies recorded ethnohistorically were often a reflection of the dramatic demographic and cultural shifts resulting from European colonialism (Sand et al. 2003; Spriggs 2008).

Much of the scholarship on social complexity in Oceania focuses on chiefs and chiefdoms (e.g. Earle and Spriggs 2015; Kirch 1984). Most contemporary Melanesian languages use some version of jif (chief) to describe individuals who hold positions of power and authority. However, the kinds of power, and how it is asserted, contested and defended, are highly variable. The evolution of chiefly systems in the Solomon Islands, for example, involved complex processes of niche construction and entanglement as people adapted to relationships of both exchange and warfare (Sheppard this volume; Thomas this volume).

Complex exchange systems evolved hand in hand with the chiefly systems, as Melanesian chiefs often relied on generosity to solidify their authority through gifts and feasting. Prestigious objects for use in exchange systems were produced through technologically sophisticated and meaningladen processes (Gaffney this volume). Remains of feasts are found in a variety of scales and materials, from faunal remains to microscopic residues found on the inside of pots (Leclerc et al. this volume). In the period of European contacts, these systems further evolved to include settlers such as missionaries (Flexner 2016; Flexner et al. this volume).

\section{The structure of this book}

The themes of diversity and complexity permeate the chapters in this volume in a number of ways. The book is separated into three main thematic sections ('Landscapes and complexities'; 'Exchange and contacts'; 'Practices'), sandwiched between smaller contextual sections. The volume opens with a historical overview covering the history of archaeological research in Island Melanesia. The chapters in 'Landscapes and complexities' examine the ways that different processes shaped social complexity and landscape transformation. 'Exchange and contacts' focuses on systems of exchange and cross-cultural interactions. 'Practices' includes in-depth examinations of different forms of practice that were essential to Melanesian ways of life. Finally, we leave the last word to our colleague Edson Willie of the Vanuatu Cultural Centre, who offers the perspective of an indigenous Melanesian archaeologist.

\section{Acknowledgements}

Funding for this publication was granted by ANU Press and the ANU Pacific Institute. 


\section{References}

Bedford, S. 2006. Pieces of the Vanuatu puzzle: Archaeology of the north, south, and centre. Terra Australis 23. Canberra: ANU E Press. doi.org/10.22459/pvp.02.2007.

Bedford, S, C Sand and SP Connaughton. 2007. Oceanic explorations: Lapita and western Pacific settlement. Canberra: ANU E Press.

Bedford, S and M Spriggs. 2014. 'The archaeology of Vanuatu: 3,000 years of history across islands of ash and coral'. In The Oxford handbook of prehistoric Oceania, edited by E Cochrane and T Hunt. Oxford: Oxford University Press. doi.org/10.1093/oxfordhb/9780199925070.013.015.

Burley, DV. 2013. 'Fijian polygenesis and the Melanesian/Polynesian divide'. Current Anthropology 54 (4):436-462. doi.org/10.1086/671195.

Clark, G. 2003. 'Dumont d'Urville's Oceania'. Journal of Pacific History 38 (2):155-161. doi.org/10.1080/ 0022334032000120503.

Clark, G and A Anderson. 2009. The early prehistory of Fiji. Terra Australis 31. Canberra: ANU E Press. doi.org/10.22459/TA31.12.2009.

Crowley, T. 2000. 'The language situation in Vanuatu'. Current Issues in Language Planning 1:47-132. doi.org/10.1080/14664200008668005.

Earle, TK and M Spriggs. 2015. 'Political economy in prehistory: A Marxist approach to Pacific sequences'. Current Anthropology 56 (4):515-544. doi.org/10.1086/682284.

Feinberg, R and R Scaglion. 2012. Polynesian Outliers: The state of the art. Pittsburgh: University of Pittsburgh Press.

Flexner, JL. 2016. An archaeology of early Christianity in Vanuatu: Kastom and religious change on Tanna and Erromango, 1839-1920. Terra Australis 44. Canberra: ANU Press. doi.org/10.22459/ TA44.12.2016.

Flexner, JL, S Bedford, F Valentin, R Shing, T Kuautonga and W Zinger. 2018. 'Preliminary results of the South Vanuatu archaeological survey: Cultural landscapes, excavation and radiocarbon dating'. Asian Perspectives 57 (2):244-266. doi.org/10.1353/asi.2018.0016.

François, A. 2012. 'The dynamics of linguistic diversity: egalitarian multilingualism and power imbalance among northern Vanuatu languages'. International Journal of the Sociology of Language 214:85-110. doi.org/10.1515/ijsl-2012-0022.

Golson, J, T Denham, P Hughes, P Swadling and J Muke. 2017. Ten thousand years of cultivation at Kuk Swamp in the Highlands of Papua New Guinea. Terra Australis 46. Canberra: ANU Press. doi.org/ 10.22459/TA46.07.2017.

Green, RC. 1991. 'Near and Remote Oceania: Disestablishing "Melanesia” in culture history'. In Man and a half: Essays in Pacific anthropology and ethnobiology in honour of Ralph Bulmer, edited by A Pawley, 481-592. Auckland: The Polynesian Society.

Kirch, PV. 1984. The evolution of the Polynesian chiefdoms. Cambridge: Cambridge University Press.

Kirch, PV. 2017. On the road of the winds: An archaeological history of the Pacific Islands before European contact. Second ed. Berkeley: University of California Press.

Kirch, PV and RC Green. 2001. Hawaiki, ancestral Polynesia: An essay in historical anthropology. Cambridge: Cambridge University Press. doi.org/10.1017/CBO9780511613678. 
Posth, C, K Nägele, H Colleran, F Valentin, S Bedford, KW Kami, R Shing, H Buckley, R Kinaston, M Walworth, G Clark, C Reepmeyer, JL Flexner, T Maric, J Moser, J Gresky, L Kiko, KJ Robson, K Auckland, SJ Oppenheimer, AVJ Hill, AJ Mentzer, J Zech, F Petchey, P Roberts, C Jeong, RD Gray, J Krause and A Powell. 2018. 'Language continuity despite population replacement in Remote Oceania'. Nature: Ecology \& Evolution 2:731-740. doi.org/10.1038/s41559-018-0498-2.

Reesink, G, R Singer and M Dunn. 2009. 'Explaining the linguistic diversity of Sahul using population models'. PLoS Biology 7 (11):e1000241. doi.org/10.1371/journal.pbio.1000241.

Richards, T, B David, K Aplin and IJ McNiven. 2016. Archaeological research at Caution Bay, Papua New Guinea: Cultural, linguistic and environmental setting. Caution Bay Studies in Archaeology 1. Oxford: Archaeopress.

Sahlins, M. 1963. 'Poor man, rich man, big-man, chief: Political types in Melanesia and Polynesia'. Comparative Studies in Society and History 5 (3):285-303. doi.org/10.1017/S0010417500001729.

Sand, C, J Bolé and A Ouetcho. 2003. 'Prehistory and its perception in a Melanesian Archipelago: The New Caledonia example’. Antiquity 77 (297):505-519. doi.org/10.1017/S0003598X00092565.

Sand, C and S Bedford. 2010. Lapita: Ancêtres Océaniens/Lapita: Oceanic ancestors. Paris: Musée de Quai Branly and Somogy Éditions d'Art.

Sand, C, S Chiu and N Hogg. 2015. The Lapita cultural complex in time and space: Expansion routes, chronologies and typologies. Nouméa: Institut d'archaeologie de la Novelle-Caledonie et du Pacific.

Scaglion, R. 1996. 'Chiefly models in Papua New Guinea'. The Contemporary Pacific 8:1-31.

Spriggs, M. 1997. The Island Melanesians. Oxford: Blackwell.

Spriggs, M. 2008. 'Ethnographic parallels and the denial of history'. World Archaeology 40 (4):538-552. doi.org/10.1080/00438240802453161.

Valentin, F, M Spriggs, S Bedford and H Buckley. 2011. 'Vanuatu mortuary practices over three millennia: Lapita to the early European Contact period'. Journal of Pacific Archaeology 2 (2):49-65.

Walter, R and P Sheppard. 2017. Archaeology of the Solomon Islands. Honolulu: University of Hawai i Press. 
This text is taken from Archaeologies of Island Melanesia: Current approaches to landscapes, exchange and practice, edited by Mathieu Leclerc and James Flexner, published 2019 by ANU Press, The Australian National University, Canberra, Australia.

doi.org/10.22459/TA51.2019.01 